\title{
Bibliometric Analysis of Economic, Social and Information Security Research
}

https://doi.org/10.21272/sec.5(2).120-128.2021

Vladislav Novikov, ORCID ID: https://orcid.org/0000-0002-4979-2438

PhD Researcher, Sumy State University, Ukraine

\begin{abstract}
Issues of national security are of particular scientific interest because without it. It is impossible to imagine the existence of any state. Protecting the economic and social interests of the population has long been one of the prerogatives of public policy, which has expanded to information security of the people in the face of rapid digitalization of all spheres of life and the introduction of information attack as a new form of weapon. In this context, it is essential to conduct a thorough study of primary scientific papers on economic, social and information security. In this work, it is proposed to use quantitative and qualitative bibliometric analysis methods, which allows to identify the main trends and form a basis for further research. The information basis for this work was the international scientometric database Scopus and SciVal by Elsevier, which allows you to analyze bibliographic data using built-in tools and import them for external use in the software VOSviewer. Bibliographic information is presented from the 1930s to June 2021. The results show that in the world, the most researched is the topic of first, social, second, information, and third, economic security. At the same time, these studies are interdisciplinary, mainly at the intersection of economic and social sciences and information security at the intersection of economic and mathematical, computer sciences. The analysis of time trends changes the number of scientific papers on economic, social and information security in Scopus database shows their gradual growth. In contrast, information security has the fastest growth rate. The study of geographical trends shows that economic security research occurs mainly in the United States, the Russian Federation and Ukraine (the funding of research confirms this at the expense of the relevant ministries and foundations). Social security is mostly studied in English-speaking and European countries (United States, United Kingdom, Germany). Information security research is concentrated in English-speaking (United States, United Kingdom) and China, India. The qualitative bibliographic analysis allowed to analyze the most cited, and hence the trend works on selected topics, confirming the multidisciplinary nature of the work. In addition, a cluster analysis of co-occurrence of keywords was coducted, which formed clusters devoted to social, economic, socio-psychological, legal and other issues.
\end{abstract}

Keywords: economic security, social security, information security, bibliometric analysis, scientometric Scopus database, SciVal database.

JEL Classification: A13, F52.

Cite as: Novikov V. (2021). Bibliometric Analysis of Economic, Social and Information Security Research. SocioEconomic Challenges, 5(2), 120-128. https://doi.org/10.21272/sec.5(2).120-128.2021.

Received: 31.03 .2021

Accepted: 14.05.2021

Published: 25.06.2021

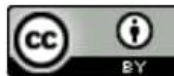

Copyright: (C) 2021 by the author. Licensee Sumy State University, Ukraine. This article is an open access article distributed under the terms and conditions of the Creative Commons Attribution (CC BY) license (https://creativecommons.org/licenses/by/4.0/).

\section{Introduction}

The need to ensure national security arose simultaneously with the creation of the first state and remained a very relevant and urgent issue. If we briefly summarize its main essence, national security aims to protect national interests from possible external or internal threats. National security as a complex category covers all spheres of public life (economic, political, social, etc.) and is divided into separate subspecies. Within the framework of this work, it was decided to focus on one of the main types of national security that form its basis: economic, social 
and information security. The allocation of information security is due to the growing role and importance of digitalization processes in society. It is the key to the transition to a new type of social relations - post-industrial (information) society and a new threat - information attacks and wars. The study of any issue logically includes the analysis of existing scientific developments, which allows identifying the relevance, central areas of research and trends. In this regard, this work aims to conduct a quantitative and qualitative bibliometric analysis of research on economic, social and information security.

\section{Literature Review}

Studies of national security have deep historical roots and have been considered together with the formation of states. According to some scholars, the beginning of the concept of the same name is attributed to the 17th century (Holmes, 2015), which was originally associated with military power and defence. However, in the second half of the twentieth century, non-military ideas of national security began to take shape, which led to the emergence of new, more applied research. In particular, to date, many scientists have studied some issues and manifestations of macroeconomic (Bouchetara et al., 2020; Musa \& Boychenko, 2018), energy (Salihaj \& Pryimenko, 2017; Ziabina et al., 2020), food (Anderson, 2018; Peng \& Berry, 2019), environmental (Zurlini \& Muller, 2008), information security (Yarovenko et al., 2020), etc. However, these studies are incomplete and require a more systematic study not individually but in combination, which is why this work is devoted.

\section{Methodology and research methods}

Like any scientific research, this work began with collecting information on scientific papers related to economic, social and communication security, it's grouping, analysis and synthesis, tabular and graphical representation. All this formed the basis for quantitative and qualitative bibliometric analysis. For this purpose, data obtained from Scopus and SciVal databases were used as one of the most well-known international scientometric databases for the available period (depending on the category but is fixed as of June 26, 2021). The databases contain the necessary statistical information and developed built-in tools that help analyze scientific trends in time, geography, thematic, etc. For a more thorough qualitative analysis, the VOSviewer software was used, which allows the graphical presentation of information in visual cluster maps.

\section{Results}

First, we will conduct a quantitative analysis of research on economic, social and information security. Table 1 first presents the general results of search queries for the keywords "economic security", social security, information security in all available subject areas. Given the specifics of this study, the search query was narrowed by areas: Economics, Econometrics and Finance, Business, Management and Accounting, which is also shown in the table in an adjacent row. The third group displays additional metrics that provide a set of SciVal by Elsevier modules - the number of Topics (as a set of documents of general intellectual interest) and Topics cluster (as a combination of topics of similar research interest).

Table 1. Quantitative composition of scientific papers on economic, social and information security in Scopus and SciVal databases

\begin{tabular}{|l|c|c|c|c|c|c|}
\hline \multirow{2}{*}{ Research category } & \multicolumn{2}{c|}{$\begin{array}{c}\text { General number of scientific } \\
\text { works }\end{array}$} & \multicolumn{2}{c|}{$\begin{array}{c}\text { Specified number of scientific } \\
\text { works }\end{array}$} & \multicolumn{2}{c|}{ Additional SciVal metrics } \\
\cline { 2 - 7 } & Scopus & SciVal & Scopus & SciVal & Topics & Topics cluster \\
\hline Economic security & 3,363 & 1,669 & 952 & 936 & 353 & 137 \\
\hline Social security & 33,077 & 18,258 & 4,752 & 4,555 & 847 & 229 \\
\hline Information security & 24,514 & 24,737 & 2,146 & 2,163 & 569 & 189 \\
\hline
\end{tabular}

Sources: complied by author via Scopus Tools, SciVal of Elsevir.

Findings show that the country's social security is a rather urgent problem, which economic scientists at the world level widely study. Information security is second place, reducing the number of works by narrowing the search for financial disciplines (because most of them were related to Computer Science). The issue of economic security is the least studied among the selected categories. 
Obtained in the system of modules SciVal Topics cluster can be grouped by subject area in the form of a bubble diagram, which is formed based on their prominence (Fig. 1). The size of the bubble depends on the scholarly output of this research area.

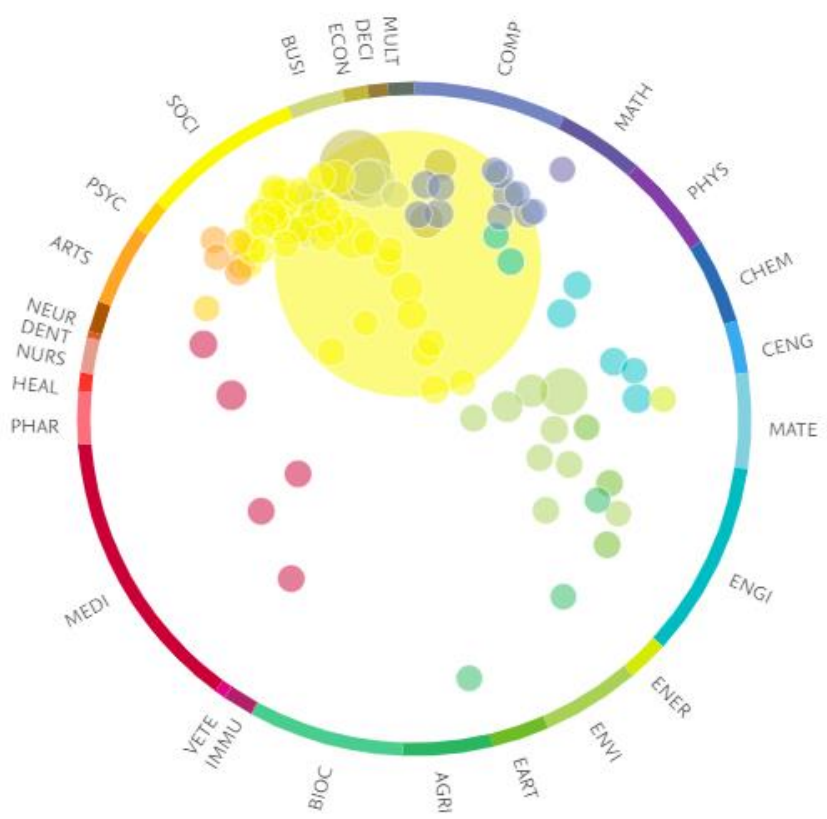

Economic security

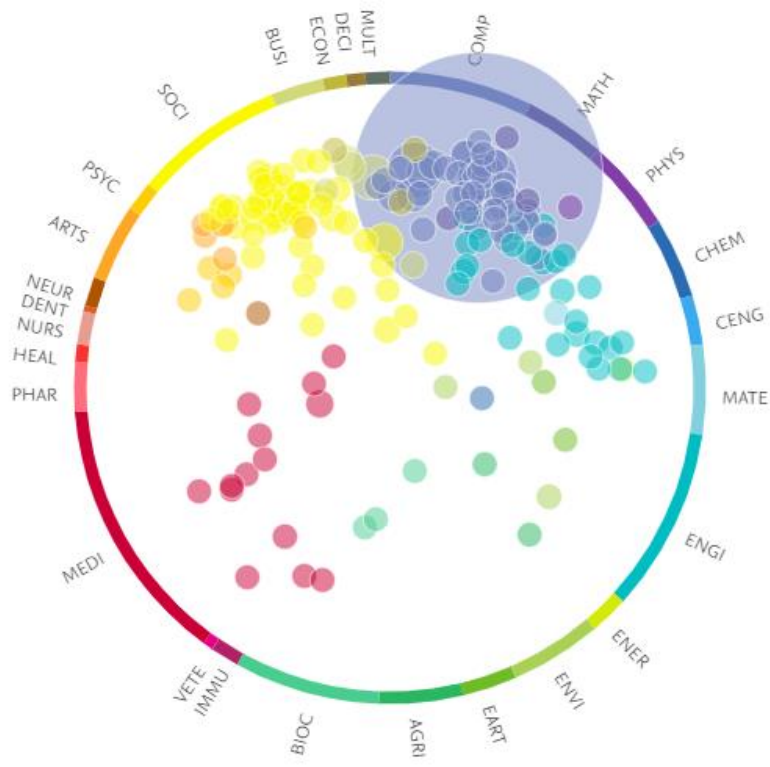

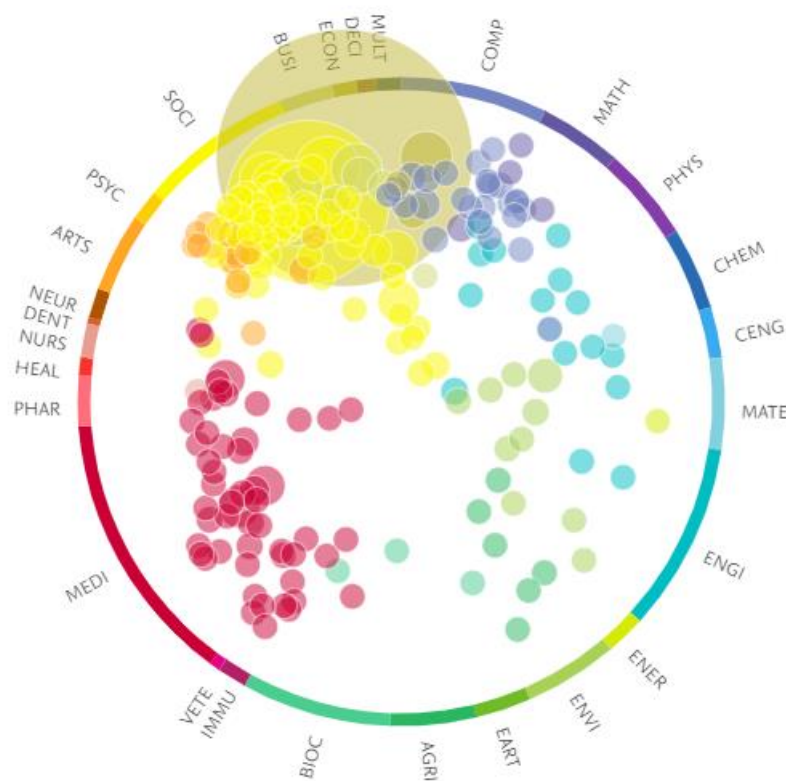

Social security

Subject area abbreviations:

AGRI-Agricultural and Biological Sciences;ARTS - Arts and Humanities; BIOC - Biochemistry, Genetics and Molecular Biology; BUSI - Business, Management and Accounting; CENG - Chemical Engineering; CHEM Chemistry; COMP - Computer Science; DECI - Decision Sciences; DENT-Dentistry; EART-Earth and Planetary Sciences; ECON - Economics, Econometrics and Finance; ENER - Energy; ENGI -Engineering; ENVI Environmental Science; HEAL - Health Professions; IMMU -Immunology and Microbiology; MATE Materials Science; MATH -Mathematics; MEDI Medicine; MULT - Multidisciplinary; NEUR Neuroscience; NURS - Nursing; PHAR - Pharmacology, Toxicology and Pharmaceutics; PHYS - Physics and Astronomy; PSYC - Psychology; SOCI-Social Sciences; VETE - Veterinary

Information security

Figure 1. Distribution of topics cluster on economic, social and information security in SciVal database $3 a$ subject area

Source: complied by author via SciVal of Elsevir.

Analyzing the bubble chart in the category of economic and social security, we note that most topics cluster are grouped into financial (Business, Management and Accounting; Economics, Econometrics and Finance) and social (Social Sciences) subject areas that tend to be multidisciplinary. Regarding thematic clusters in information 
security, there is a shift of research towards the exact sciences (Computer Science; Mathematics). Consider the top 3 topics cluster (most enormous bubbles in Figure 1) for economic, social and information security, obtained using the SciVal metric in Table 2. The system's names are automatically generated by the system, which generally characterizes the articles included in it. For example, the first cluster of the economic security bloc, in our opinion, is incorrectly named because it has, among other things, institutional and managerial aspects of financial security, energy issues, and so on. The Prominence indicator, which according to the SciVal reference information is an indicator of momentum and is obtained as the average of the indicators of the number of citations, views and growth of CiteScore.

Table 2. Metrics tor-3 topics cluster on economic, social and information security in SciVal databases

\begin{tabular}{|c|c|c|c|c|}
\hline Topic cluster & $\begin{array}{c}\text { Scholarly } \\
\text { output }\end{array}$ & Publication share & $\begin{array}{l}\text { Field-weighted } \\
\text { citation impact }\end{array}$ & $\begin{array}{l}\text { Prominence } \\
\text { percentile }\end{array}$ \\
\hline \multicolumn{5}{|c|}{ Economic security } \\
\hline Students; Russian; Education (TC.1114) & 238 & $0.85 \%$ decline & 0.65 & 77.324 \\
\hline $\begin{array}{l}\text { Monetary Policy; Economic Growth; Exports } \\
\text { (TC.21) }\end{array}$ & 46 & $0.05 \%$ growth & 0.46 & 94.448 \\
\hline Industry; Innovation; Entrepreneurship (TC.24) & 23 & $0.02 \%$ growth & 0.79 & 98.997 \\
\hline \multicolumn{5}{|c|}{ Social security } \\
\hline $\begin{array}{l}\text { Monetary Policy; Economic Growth; Exports } \\
\text { (TC.21) }\end{array}$ & 492 & $0.51 \%$ decline & 0.62 & 94.448 \\
\hline Pensions; Financial Literacy; Retirement (TC.1067) & 293 & $3.04 \%$ decline & 0.63 & 38.796 \\
\hline Taxes; Tax Evasion; Tax Compliance (TC.920) & 86 & $0.77 \%$ decline & 0.62 & 42.876 \\
\hline \multicolumn{5}{|c|}{ Information security } \\
\hline $\begin{array}{llll}\text { Computer Crime; Network Security; Intrusion } \\
\text { Detection (TC.218) }\end{array}$ & 566 & $0.81 \%$ decline & 1.16 & 95.518 \\
\hline $\begin{array}{l}\text { Cryptography; Authentication; } \\
\text { (TC.84) }\end{array}$ & 93 & $0.10 \%$ decline & 1.81 & 97.993 \\
\hline Industry; Information Systems; Research (TC.254) & 80 & $0.22 \%$ decline & 0.86 & 87.023 \\
\hline
\end{tabular}

Source: complied by author via SciVal of Elsevir.

As can be seen from Table 2, the thematic clusters from the social security block are closely intertwined with economic issues and in the information security block - with computer science. Based on this information, it was decided to analyze further the narrow sample of scientific papers on economic orientation.

Let's move on to further quantitative research of scientific papers on economic, social and information security in time. The first mention of financial security dates back to 1948 (in the form of a resolution of the Inter-American Conference for the Maintenance of Continental Peace and Security), social security - in 1937, information - in 1982. After that, the number of papers gradually increased. Figure 2 shows the change in the number of works on selected search queries from 1982 to 2020 . As of 2020, the Scopus database presents 100 results related to economic security, 233 - social and 196 - information. At the same time, the growth of research on information security has a fairly rapid growth, which in 2019 was equal to the number of research on social security.

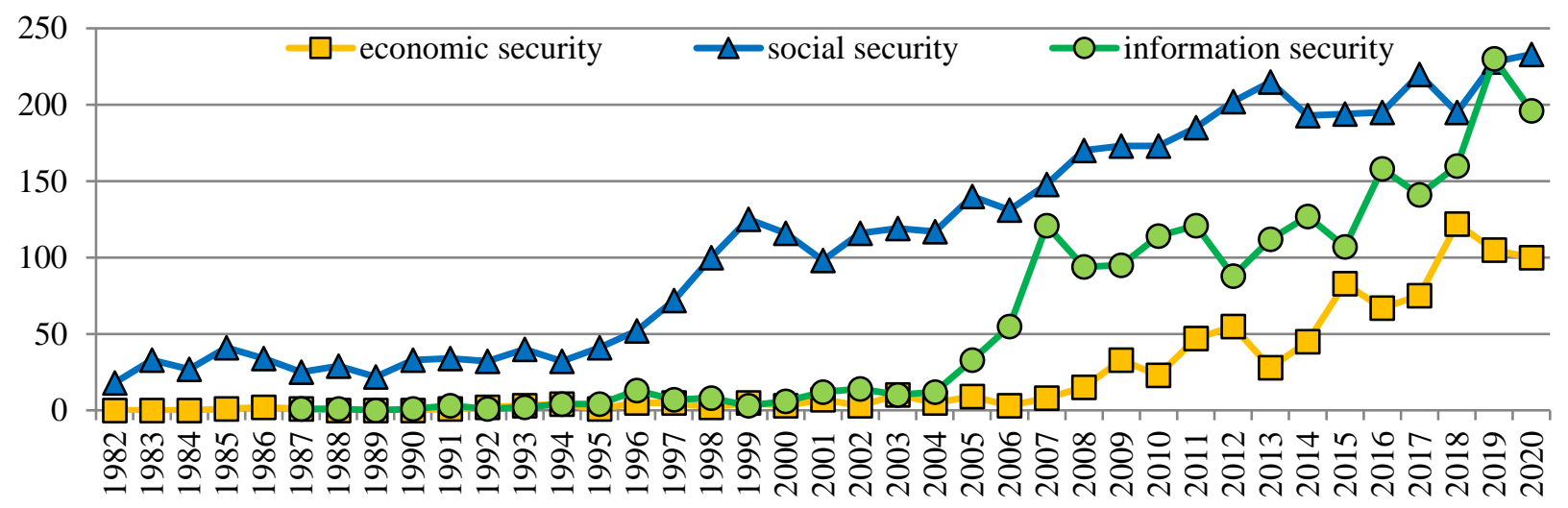




\section{Figure 2. Dynamics of the number of scientific papers on economic, social and information security in the Scopus database for 1982-2020}

Sources: complied by authors via Scopus Tools.

The number of works on selected topics varies in the geographical dimension. That is why Table 3 shows the top 15 countries with the most significant number of scientific papers.

Table 3. Quantitative composition of scientific papers on economic, social and information security in Scopus database in the geographical dimension

\begin{tabular}{|l|c|l|c|l|c|}
\hline \multicolumn{2}{|c|}{ Economic security } & \multicolumn{2}{c|}{ Social security } & \multicolumn{2}{c|}{ Information security } \\
\hline Country/Territory & Documents & Country/Territory & Documents & Country/Territory & Documents \\
\hline United States & 530 & United States & 3534 & United States & 1392 \\
\hline Russian Federation & 365 & United Kingdom & 1429 & China & 467 \\
\hline Ukraine & 233 & Germany & 834 & United Kingdom & 305 \\
\hline United Kingdom & 167 & China & 507 & Russian Federation & 202 \\
\hline Canada & 86 & Netherlands & 425 & India & 194 \\
\hline Australia & 81 & Australia & 408 & South Africa & 189 \\
\hline China & 54 & Spain & 375 & Australia & 164 \\
\hline India & 53 & France & 364 & Germany & 121 \\
\hline Germany & 35 & Italy & 334 & South Korea & 119 \\
\hline Kazakhstan & 31 & Canada & 333 & Taiwan & 111 \\
\hline Poland & 31 & India & 281 & Malaysia & 110 \\
\hline Singapore & 28 & Belgium & 253 & Sweden & 104 \\
\hline Netherlands & 27 & Switzerland & 231 & Canada & \\
\hline Sweden & 25 & Japan & Greece & 89 \\
\hline
\end{tabular}

Sources: complied by authors via Scopus Tools.

The leader of scientific research in all areas is the United States. Interestingly, economic security is widely studied in the Russian Federation and Ukraine (2nd and 3rd places in the top 15), and only then in such English-speaking countries as the United Kingdom, Canada, Australia. Social security is the subject of numerous studies in European countries (United Kingdom, Germany, Netherlands, etc.) and China. Information security is considered by scientists in the United States, United Kingdom, China, and the Russian Federation, India, South Africa and others.

According to the results obtained above, there is a distribution of scientific papers for funding sponsor. The leaders in the category of economic security are the Russian Foundation for Basic Research (19 works), the Russian Science Foundation (10 works), the Ministry of Education and Science of Ukraine (5 works) and the Russian Federation (4 works). For the social security category, the main funding organizations are U.S. Department of Health and Human Services (67 papers), National Institutes of Health (66 papers), U.S. Social Security Administration (58 papers), National Institute on Aging (55 papers), European Commission (49 papers). Research on information security is funded mainly by the National Science Foundation (35 works), National Natural Science Foundation of China (28 works), European Commission (13 works), Russian Foundation for Basic Research (13 works), Ministry of Education of the People's Republic of China (12 works). Thus, the study of information security in India, South Africa is mostly carried out by scientists themselves.

The next step is to move to a qualitative analysis of scientific papers. In table 3 we consider the top 5 most cited works in the Scopus database for each search query economic security, social security, information security. A qualitative analysis of the most cited works on selected topics allows us to draw the following conclusions. In general, the work on the economic security block concerns the impact of certain factors on it: scientific and technical, financial (through the prism of financial risks), social (development of entrepreneurship and financial inclusion among women), economic (through the formation of a more applied index of economic well-being). In addition, the social security block is related to issues related to the role of economic levers (e.g. government bonds, individual savings for the population) and social and labor issues (regulation of labor markets through employment laws, collective relations and social security, birth rate regulation). The works singled out in the 
information security block are mainly considered at the meso level (business) and relate to the optimization of economic commerce and the prevention of systemic and other information risks in enterprises.

Table 4. TOP-5 most cited articles for search queries economic security, social security, information security in Scopus database

\begin{tabular}{|c|c|c|c|}
\hline Cited by & Authors & Document title & Source(Year) \\
\hline \multicolumn{4}{|c|}{ Economic security } \\
\hline 1354 & Partha, D., David, P.A. & Toward a new economics of science & Research Policy (1994) \\
\hline 231 & Shiller, R.J. & The new financial order: Risk in the 21 st century & $\begin{array}{l}\text { The New Financial Order: } \\
\text { Risk in the 21st Century } \\
(2009)\end{array}$ \\
\hline 179 & Datta, P.B., Gailey, R. & $\begin{array}{c}\text { Empowering Women Through Social } \\
\text { Entrepreneurship: Case Study of a Women's } \\
\text { Cooperative in India }\end{array}$ & $\begin{array}{l}\text { Entrepreneurship: Theory } \\
\text { and Practice (2012) }\end{array}$ \\
\hline 141 & $\begin{array}{l}\text { Schuler, S.R., Hashemi, } \\
\text { S.M., Riley, A.P. }\end{array}$ & $\begin{array}{l}\text { The influence of women's changing roles and status } \\
\text { in Bangladesh's fertility transition: Evidence from } \\
\text { a study of credit programs and contraceptive use }\end{array}$ & World Development (1997) \\
\hline 123 & Osberg, L., Sharpe, A. & $\begin{array}{l}\text { An index of economic well-being for selected } \\
\text { OECD countries }\end{array}$ & $\begin{array}{l}\text { Review of Income and } \\
\text { Wealth (2002) }\end{array}$ \\
\hline \multicolumn{4}{|c|}{ Social security } \\
\hline 2195 & Barro, R.J. & Are government bonds net wealth? & $\begin{array}{l}\text { Journal of Political Economy } \\
\text { (1974) }\end{array}$ \\
\hline 1131 & Madrian, B.C., Shea, D.F. & $\begin{array}{l}\text { The power of suggestion: Inertia in } 401(\mathrm{k}) \\
\text { participation and savings behavior }\end{array}$ & $\begin{array}{l}\text { Quarterly Journal of } \\
\text { Economics (2001) }\end{array}$ \\
\hline 977 & $\begin{array}{l}\text { Botero, J.C., Djankov, S., La } \\
\text { Porta, R., Lopez-De-Silanes, F., } \\
\text { Shleifer, A. }\end{array}$ & The regulation of labor & $\begin{array}{l}\text { Quarterly Journal of } \\
\text { Economics (2004) }\end{array}$ \\
\hline 699 & $\begin{array}{l}\text { Ariely, D., Loewenstein, G., } \\
\text { Prelec, D. }\end{array}$ & $\begin{array}{l}\text { "Coherent arbitrariness": Stable demand curves } \\
\text { without stable preferences }\end{array}$ & $\begin{array}{l}\text { Quarterly Journal of } \\
\text { Economics (2003) }\end{array}$ \\
\hline 598 & Becker, G.S., Barro, R.J. & $\begin{array}{l}\text { A reformulation of the economic theory of } \\
\text { fertility }\end{array}$ & $\begin{array}{l}\text { Quarterly Journal of } \\
\text { Economics (1988) }\end{array}$ \\
\hline \multicolumn{4}{|c|}{ Information security } \\
\hline 1361 & $\begin{array}{l}\text { Pavlou, P.A., Huigang, L., } \\
\text { Yajiong, X. }\end{array}$ & $\begin{array}{c}\text { Understanding and mitigating uncertainty in } \\
\text { online exchange relationships: A principal-agent } \\
\text { perspective }\end{array}$ & $\begin{array}{l}\text { MIS Quarterly: Management } \\
\text { Information Systems (2007) }\end{array}$ \\
\hline 958 & $\begin{array}{l}\text { Bulgurcu, B., Cavusoglu, H., } \\
\text { Benbasat, I. }\end{array}$ & $\begin{array}{l}\text { Information security policy compliance: An } \\
\text { empirical study of rationality-based beliefs and } \\
\text { information security awareness }\end{array}$ & $\begin{array}{l}\text { MIS Quarterly: Management } \\
\text { Information Systems (2010) }\end{array}$ \\
\hline 747 & Straub, D.W., Welke, R.J. & $\begin{array}{l}\text { Coping with systems risk: Security planning } \\
\text { models for management decision making }\end{array}$ & $\begin{array}{l}\text { MIS Quarterly: Management } \\
\text { Information Systems (1998) }\end{array}$ \\
\hline 680 & Johnston, A.C., Warkentin, M. & $\begin{array}{c}\text { Fear appeals and information s ecurity behaviors: } \\
\text { An empirical study }\end{array}$ & $\begin{array}{l}\text { MIS Quarterly: Management } \\
\text { Information Systems (2010) }\end{array}$ \\
\hline 504 & Straub Jr., D.W. & Effective IS security: An empirical study & $\begin{array}{l}\text { Information Systems } \\
\text { Research (1990) }\end{array}$ \\
\hline
\end{tabular}

Sources: complied by authors via Scopus Tools.

In addition to the qualitative bibliometric analysis, we will cluster keywords found in scientific papers related to economic, social and information security using VOSviewer software. The co-occurrence of keywords was chosen as the method of analysis. The data extracted from the Scopus database and processed in the program, which is normalized by the fractionalization method, were selected as the basis. As a result of clustering, the following results were obtained:

- for the economic security block (Fig. 3): based on 359 items (keywords) 6 clusters, 8050 links (co-occurrences) with 14944 total link strength (number of publications in which two terms occur together) were formed;

- for the social security block: based on 321 items 4 clusters, 7941 links from 19635 total link strength are formed; - for the block of information security: based on 313 items, 4 clusters, 7504 links from 17951 total link strength are formed. 
Cluster analysis for economic security is the most general, as it includes references to social and economic security. Let's analyze the obtained clusters in Figure 3:

- the first cluster (red, 120 items) related to social issues of economic security: poverty, migration, employment and unemployment, working conditions, disability, etc. In particular, there is a category of social security;

- the second cluster (green, 116 items) related to economic security issues: energy security, financial security, foreign economic activity, business, economic policy, digital economy, etc. In particular, there is a category of information security;

- the third cluster (blue, 61 items) related to socio-psychological issues, in particular: the formation of social capital, living conditions and well-being of people, women, children, people with disabilities, displaced persons, etc.;

- the fourth cluster (yellow, 38 items) related to the legal aspects of economic security to ensure decent pensions, social assistance, care in case of illness;

- fifth cluster (purple, 13 items) related to the situation due to the coronary viral disease pandemic and its consequences;

- sixth cluster (blue, 11 items) related to issues of gender equality and relations in society.

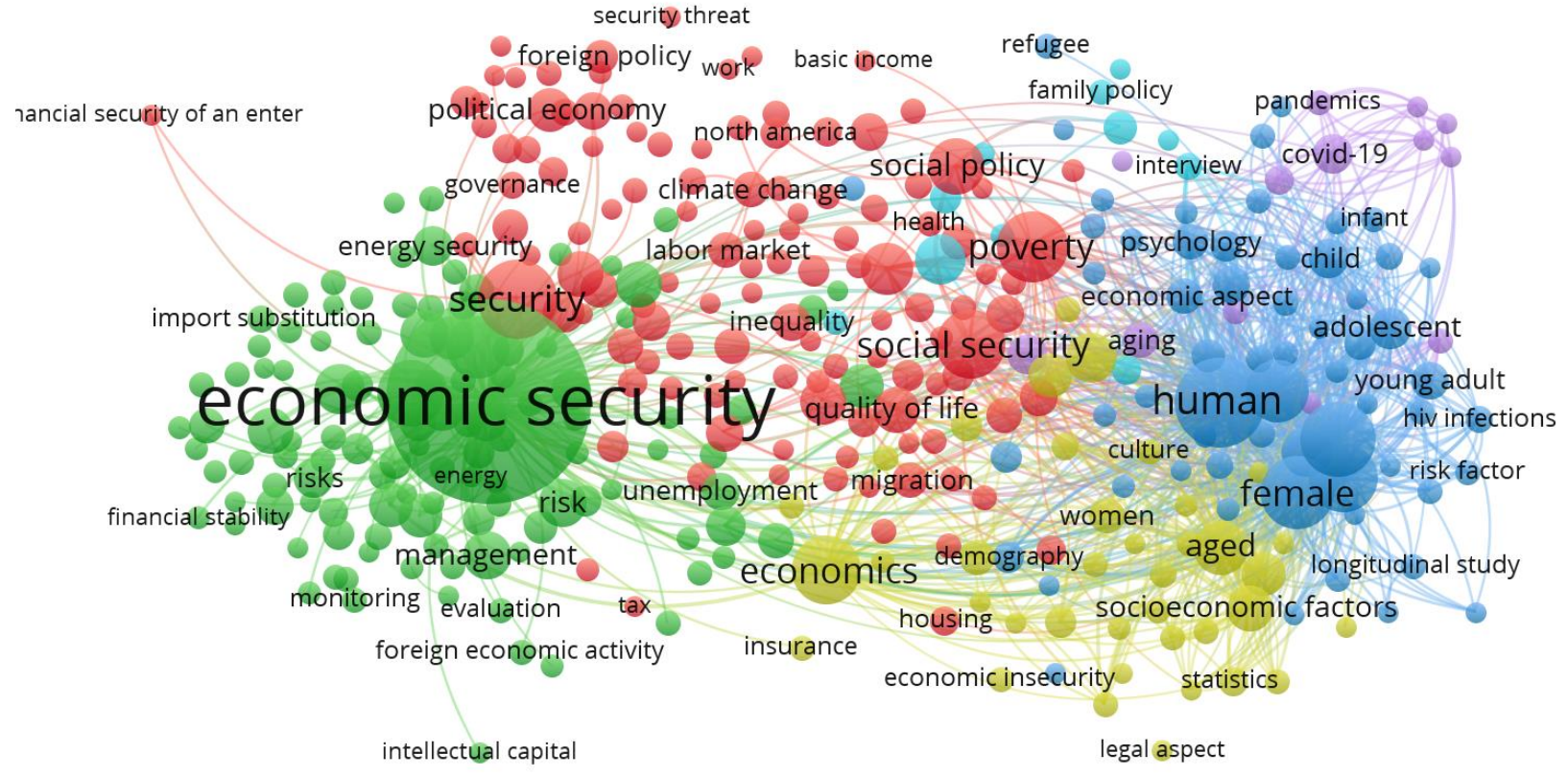

Figure 3. Cluster analysis of co-occurrence of keywords on economic security in Scopus database

Sources: complied by authors via VOSviewer.

As we can see, the research is closely interdisciplinary, manifested in the presentation of economic, social, and information issues to ensure the country's national security.

\section{Conclusions}

This study was devoted to the quantitative and qualitative bibliometric analysis of research on economic, social and information security using Scopus database. To achieve this goal, the author analyzed the quantitative composition of scientific papers on specific topics, considered the dynamics of their change, subject areas and geography of distribution, qualitative analysis of the most cited works and cluster analysis of co-occurrence of keywords.

As a result, it was found that most research is devoted to social and information security, least of all economic. 
The research of the subject areas in which these researches took place forced to narrow the search to the economic direction (Economics, Econometrics and Finance, Business, Management and Accounting). Numerous studies have been conducted in the social and computer sciences, which are not of scientific interest within our work. The first works recorded in the Scopus database date back to 1937-1982, after which the number of works gradually increased (with social security being ahead of others). Most research in all areas belongs to the United States. For economic security are Ukraine and Russia, social - English-speaking and European countries, and information security - China, Britain, Russia, India.

Qualitative analysis of the most cited works revealed the following trends: for economic security, works on factor impact (financial, social, scientific and technical indicators, etc.) are most often cited; for social security - on the role of economic levers and social and labor regulation; for information security - to prevent the loss of information and avoid other risks in enterprises. As a result of clustering of keywords found in scientific papers related to economic, social and information security, the interdisciplinarity of research is re-emphasized, as there are clusters related to social, economic, socio-psychological, legal and other issues.

Funding: self-funded.

Author Contributions: conceptualization: Novikov, V.; data curation: Novikov, V.; formal analysis: Novikov, V.; funding acquisition: Novikov, V.; investigation: Novikov, V.; methodology: Novikov, V.; project administration: Novikov, V.; resources: Novikov, V.; software: Novikov, V.; supervision: Novikov, V.; validation: Novikov, V.; visualization: Novikov, V.; writing - original draft: Novikov, V.; writing- review and editing: Novikov, V.

Acknowledgment. The article was published as part of a research projects "Convergence of economic and educational transformations in the digital society: modeling the impact on regional and national security" (No. 0121U109553) and "Reforming the lifelong learning system in Ukraine for the prevention of the labor emigration: a coopetition model of institutional partnership" (No. 0120U102001).

\section{References}

1. Anderson, J. R. (2018). Concepts of food stability in food security. In: Ferranti, P., Berry, E., Anderson, J.R. (Eds.), Encyclopedia of Food Security and Sustainability. Elsevier, Oxford. Available at: [CrossRef].

2. Ariely, D., Loewenstein, G., \& Prelec, D. (2003). "Coherent arbitrariness": Stable demand curves without stable preferences. Quarterly Journal of Economics, 118(1), 73-105. Available at: [CrossRef].

3. Barro, R. J. (1974). Are government bonds net wealth? Journal of Political Economy, 82(6), 1095-1117. Available at: [CrossRef].

4. Becker, G. S., \& Barro, R. J. (1988). A reformulation of the economic theory of fertility. Quarterly Journal of Economics, 103(1), 1-25. Available at: [CrossRef].

5. Botero, J. C., Djankov, S., La Porta, R., Lopez-De-Silanes, F., \& Shleifer, A. (2004). The regulation of labor. Quarterly Journal of Economics, 119(4), 1339-1382. Available at: [CrossRef].

6. Bouchetara, M., Nassour, A., Eyih, S. (2020). Macroprudential policy and financial stability, role and tools. Financial Markets, Institutions and Risks, 4(4), 45-54. Available at: [CrossRef].

7. Bulgurcu, B., Cavusoglu, H., \& Benbasat, I. (2010). Information security policy compliance: An empirical study of rationality-based beliefs and information security awareness. MIS Quarterly: Management Information Systems, 34(SPEC. ISSUE 3), 523-548. Available at: [CrossRef].

8. Datta, P. B., \& Gailey, R. (2012). Empowering women through social entrepreneurship: Case study of a women's cooperative in India. Entrepreneurship: Theory and Practice, 36(3), 569-587. Available at: [CrossRef].

9. Holmes, K. R. (2015). What Is National Security? Index of U.S. Military Strength. The Heritage foundation, 17-26. Available at: [Link].

10. Johnston, A. C., \& Warkentin, M. (2010). Fear appeals and information s ecurity behaviors: An empirical study. MIS Quarterly: Management Information Systems, 34(SPEC. ISSUE 3), 549-566. Available at: [CrossRef]. 
11. Madrian, B. C., \& Shea, D. F. (2001). The power of suggestion: Inertia in 401(k) participation and savings behavior. Quarterly Journal of Economics, 116(4), 1149-1187. Available at: [CrossRef].

12. Musa A. Subeh, Boychenko V. (2018). Causes, Features and Consequences of Financial Crises: a retrospective cross-country analysis. Financial Markets, Institutions and Risks, 2(2), 111-122. Available at: [CrossRef].

13. Osberg, L., \& Sharpe, A. (2002). An index of economic well-being for selected OECD countries. Review of Income and Wealth, 48(3), 291-316. Available at: [CrossRef].

14. Partha, D., \& David, P. A. (1994). Toward a new economics of science. Research Policy, 23(5), 487-521. Available at: [CrossRef].

15. Pavlou, P. A., Huigang, L., \& Yajiong, X. (2007). Understanding and mitigating uncertainty in online exchange relationships: A principal-agent perspective. MIS Quarterly: Management Information Systems, 31(1), 105-135. Available at: [CrossRef].

16. Peng, W., Berry, E.M. (2019). The Concept of Food Security. In: Ferranti, P., Berry,E.M., Anderson, J.R. (Eds.), Encyclopedia of Food Security and Sustainability, vol. 2,pp. 1-7. Elsevier. Available at: [CrossRef].

17. Salihaj, T., Pryimenko, S. (2017). Modification of the International Energy Agency Model (the IEA Model of Short-term Energy Security) for Assessing the Energy Security of Ukraine. SocioEconomic Challenges, 1(4), 95-103. Available at: [CrossRef].

18. Schuler, S. R., Hashemi, S. M., \& Riley, A. P. (1997). The influence of women's changing roles and status in bangladesh's fertility transition: Evidence from a study of credit programs and contraceptive use. World Development, 25(4), 563-575. Available at: [CrossRef].

19. Shiller, R. J. (2009). The new financial order: Risk in the 21st century. The new financial order: Risk in the 21st century (pp. 1-366) Available at: [Link].

20. Straub Jr., D. W. (1990). Effective IS security: An empirical study. Information Systems Research, 1(3), 255276. Available at: [CrossRef].

21. Straub, D. W., \& Welke, R. J. (1998). Coping with systems risk: Security planning models for management decision making. MIS Quarterly: Management Information Systems, 22(4), 441-464. Available at: [CrossRef].

22. Van Eck N.J., Waltman L. (2010). Software survey: VOSviewer, a computer program for bibliometric mapping. Scientometrics, 84(2), 523-538. Available at: [CrossRef].

23. Yarovenko, H., Kuzmenko, O., Stumpo, M. (2020). Strategy for Determining Country Ranking by Level of Cybersecurity. Financial Markets, Institutions and Risks, 4(3), 124-137. Available at: [CrossRef].

24. Ziabina, Ye., Pimonenko, T., Starchenko, L. (2020). Energy Efficiency Of National Economy: Social, Economic And Ecological Indicators. SocioEconomic Challenges, 4(4), 160-174. Available at: [CrossRef].

25. Zurlini, G., Mu 1ler, F. (2008). Environmental Security. In Sven Erik Jørgensen and Brian D. Fath (Editor-inChief), Systems Ecology. Vol. [2] of Encyclopedia of Ecology,5 vols. pp. 1350-1356. Oxford: Elsevier. Available at: [CrossRef]. 